doi: 10.32620/oikit.2020.89.07

UDC 629.735.33-521

В.С. Долгих

\title{
Аналіз особливостей проектування безпілотного транспортного літака щодо паливної ефективності
}

\author{
Національний аерокосмічний університет ім. М. Є. Жуковського \\ "Харківський авіаційний інститут»
}

Застосування безпілотних літальних систем знаходиться на початковій стадії, що характеризується відсутністю підстав для застосування безпілотних літальних апаратів у реальних технологічних процесах, хоча розвиток безпілотних літальних апаратів та їх елементів викликає підвищений інтерес. Вирішення цього протиріччя потребує вирішування різноманітних проблем концептуального, технічного, технологічного, методологічного, організаційно-правового та нормативного характеру.

Загалом сьогодні застосування безпілотних авіаційних систем у цивільній галузі практично обмежене окремими випадками місцевих застосувань на користь вирішення поточних виробничих або економічних проблем, головним чином шляхом експериментальної процедури. Отже, очікується розвиток ринку безпілотних літальних систем, що забезпечить можливість подолання ряду технічних та адміністративних бар'єрів, що обмежують використання безпілотних літальних систем у національному повітряному просторі. Слід також зазначити все більше поширення безпілотних систем у загальному транспорті.

Проведення такого дослідження було мотивовано зростаючим у всьому світі інтересом до безпілотних вантажних літаків. Його було зосереджено, зокрема, на вантажних безпілотниках на базі існуючих звичайних літаків загальної авіації, і це слід розглядати як попередній крок до комплексного оцінювання безпілотних вантажних транспортних систем. Метою було оцінити ефективність використання палива такими безпілотними системами та окреслити оптимальні параметри деяких їх ключових конструктивних характеристик. Було досліджено 26 зразків надлегких та легких літальних апаратів та мотопланерів. Дані використано з відкритих джерел. Результати показують, що для найкращої економії палива вантажний безпілотник має бути композитною конструкцією, літаком з поршневим двигуном із подовженням крила від 10 до 12. Оцінювання ефективності використання палива на відстанях від 500 до 2500 км свідчить, що такі вантажні безпілотники будуть конкурентоспроможними 3 великими пілотованими комерційними вантажними літаками, а також автомобільним транспортом.

Ключові слова: безпілотні літальні апарати (БПЛА), безпілотні транспортні літаки (БТЛ), платфрорма для безпілотних транспортних літаків (ПБТЛ), літаки надлегкого класу (ЛНК).

\section{Вступ}

Україна $є$ однією з небагатьох країн, що мають потужний потенціал в авіаційному проектуванні та авіаційній промисловості. За останні роки було зроблено значний внесок у розвиток літакобудівної промисловості, що дало змогу подолати відставання в потенційному напрямку розроблення безпілотних авіаційних систем і зайняти конкурентні позиції у виробництві та експлуатації безпілотних авіаційних систем [1].

Складна економічна ситуація змушує шукати найдешевші способи роботи. Будівництво безпілотних авіаційних систем переважно невеликих розмірів є одним із цих напрямків, що дозволяє реалізувати професійні амбіції, нові ідеї та досвід у створення кінцевої продукції [2].

Сьогодні, як очікується, запровадження безпілотних автономних транспортних систем принесе значні вигоди та економію. Ці очікування охоплюють також авіаційні вантажі, що відображено у багатьох стратегічних 
документах, таких, як IATA Cargo Strategy [3] та Європейської комісії Flightpath 2050 [4]. Первинний інтерес з боку кур'єрських компаній та компаній електронної комерції було зосереджено на так званих безпілотних літаках для доставки дрібних предметів «останньої милі». Одночасно з'явилося багато стартапів, спрямованих на створення більш важких безпілотних транспортних літаків (БТЛ) з більшою дальністю. Ця діяльність привела до введення такого поняття, як платфрорма для безпілотних транспортних літаків (ПБТЛ). Більшість проектів стосується літаків з корисним навантаженням від однієї до десяти тонн. Багато практичної роботи було проведено в Китаї, створені вантажні безпілотники на базі існуючих легких літаків загальної авіації, таких, як Staruas AT200.

Важливим кроком до реалізації концепцій вантажних безпілотників $€$ оцінювання їх енергетичної та транспортної ефективності. Огляд проблеми ефективності безпілотних літальних апаратів (БПЛА) не зосереджено тільки на вантажних безпілотниках [5]. Показники витрат БПЛА можуть бути використані також для оцінки енергетичної ефективності [6].

Особливо для випадку доставки безпілотників «останньої милі» аналізи ефективності були проведені дослідниками, яких фрінансує Міністерство енергетики США [7] та RAND [8]. Більш масштабні дослідження БТЛ було проведено під егідою ПБТЛ [9, 10], щоб охопити широку область аспектів комерційного впровадження БТЛ. У той же час немає досліджень, присвячених сегменту UCA, які мають дальність і корисне навантаження, що відповідають цим літакам надлегкого класу (ЛНК).

Метою цього дослідження $€$ оцінювання паливної ефективності такого БТЛ та його використання для подальших досліджень їх експлуатації та ефрективності як транспортної системи. Підхід, використаний для оцінювання, $€$ спільним із підходом до подібних досліджень, що стосуються пасажирської авіації. Різниця полягає в тому, що використовуються дані щодо існуючих легких і дуже легких літальних апаратів та деякі припущення щодо переобладнання пілотованого літального апарату в безпілотний. Також розглядається вплив на економію палива деяких ключових конструктивних особливостей літака, таких, як тип матеріалів, що використовуються в планерах, і подовження крила.

\section{Основа оцінювання}

Слід зазначити, що реальна продуктивність майбутнього БТЛ буде залежати від великої кількості конструктивних особливостей. Складність завдання проектування БТЛ можна побачити при порівнянні різних типів літальних апаратів та вертольотів, що відповідають різним вимогам. Метою даної роботи є не аналіз різноманітності всіх можливих типів БТЛ, а оцінювання енергоефективності БТЛ, яке можна виконати на основі енергоефективності існуючих літаків загальної авіації, використовуючи ті ж самі технології планера та двигуна.

\section{Припущення щодо переобладнання вантажних літаків на БТЛ}

Чотири основні характеристики, які мають великий вплив на енергоефективність літака, - це його маса, аеродинамічні властивості, ефективність силової установки та енергоспоживання систем. Для достовірного оцінювання енергоефективності БТЛ при використанні даних для пілотованих літальних апаратів, важливо правильно визначіти, як ці характеристики будуть 
впливати на вимоги до конструкції БТЛ. У цій роботі пропонуються такі зміни в проектуванні:

- відсутність кабіни в БТЛ дозволить поліпшити аеродинамічну форму носової частини фююзеляжу, а у випадку одного двигуна з гвинтом вище розташувати двигун, що приведе до укорочення стійок шасі, які легше і створюють менший повітряний опір;

- відсутність обладнання та крісел для пілотів, а також механічної системи управління польотом зменшить масу літака;

- потреба у відносно великому вантажному об“ємі для кабіни пілотів та відповідних посадкових дверях матиме негативний вплив на масу планера та аеродинамічний опір порівняно з пілотованим ЛНК;

- відсутність польотних приладів в кабіні пілотів компенсується додаванням датчиків та систем автопілота з точки зору ваги та енергоспоживання;

- використання приводів контрольних поверхонь збільшить масу літака та споживання енергії.

Усі зазначені вище міркування потребують окремих досліджень. 3 цієї причини в даній роботі запропоновано «нейтральний» сценарій, припускаючи, що перетворення літаків на БТЛ не вплине суттєво на масу порожнього літака, а всі наявні навантаження будуть поділені між паливом та корисним навантаженням, а аеродинамічні властивості залишаться по суті незмінними.

\section{Літаки, включені в дослідження}

Було досліджено 26 зразків надлегких та легких літальних апаратів та мотопланерів на основі даних про експлуатаційні характеристики, наведених в Інтернеті виробниками, та даних відповідних таблиць сертифікатів типу. Їх можна поділити на такі групи:

- ЛНК з планером з алюмінієвого сплаву, бензиновим двигуном Rotax 912/914 (10 літаків);

- ЛНК з композитним планером, бензиновим двигуном Rotax 912/914 (9 літаків);

- мотопланери з композитним планером, бензиновим двигуном Rotax 912/914 (3 літаки);

- мотопланери з планером з алюмінієвого сплаву, бензиновим двигуном Rotax 912/914 (2 літаки);

- легкі літаки на дизельному двигуні з композитним планером (2 літаки);

- турбогвинтовий БТЛ АТ200 на основі службового літака РАС-750 взято за еталон.

ЛНК є найпопулярнішою категорією літаків загальної авіації, які широко використовуються для навчання пілотів та прогулянкових польотів. Більшість 3 цих літаків мають порівняно нові конструкції та оснащені двигунами сімейства Rotax 912/914, в яких застосовують автомобільний бензин замість дорожчого авіаційного палива.

Літаки з дизельним двигуном вирізняються низькою питомою витратою палива. Застосування цих двигунів в загальній авіації було обмежено успішним впровадженням авіаційних поршневих двигунів, сертифікованих для автомобільних бензинів. Однак дизельні двигуни використовують також у для військових БПЛА. 


\section{Метод оцінки паливної ефективності}

Показники для розрахунку паливної ефективності вантажних літаків Існують різні показники для вимірювання економічних параметрів комерційних літаків [10-13]. У даній роботі таким показником вибрана енергоємність, яка не залежить від типу двигуна та палива. У випадку вантажного літака енергоємність:

$$
E_{i}=\frac{m_{n} \cdot H_{3}}{1000 m_{\text {кop }} L_{f t}},
$$

де $m_{n}$ - маса палива, витраченого на політ, кг; $H_{3}$ - чиста теплота згоряння палива, МДж/кг; $m_{\text {кор }}$ - корисне навантаження, кг; $L_{f t t}-$ відстань польоту, км. Енергоємність $E_{i}$ може бути виміряна в МДж(тонн·км $)^{-1}$, або кДж(кг-км $)^{-1}$.

\section{Розрахунок витрати палива}

Щоб подолати відсутність детальних даних про ефективність витрати палива для розрахунків дальності, використаємо підхід, подібний до того, що був використаний в [14]. Замість питомої витрати палива (TSFC) застосовано коефріцієнт підйому та опору $(L / D)$ у рівнянні Бреге:

$$
L_{n o . n}=\frac{V_{k p} L / D}{T S F C g} \ln \left(\frac{m_{3 n}}{m_{3 n}-m_{n}}\right),
$$

де $m_{3 л}$ - злітна маса літака, а $V_{\kappa p}$ - крейсерська швидкість.

Коефріцієнт Бреге:

$$
B F=\frac{V_{k p} L / D}{T S F C g} .
$$

За допомогою рівняння (2) можна розрахувати коефіцієнт Бреге для кожного літака, а також максимальну дальність і максимальну корисну ємність палива:

$$
B F=L_{\text {nо. } \max }\left[\ln \left(\frac{m_{3 n}}{m_{3, n}-m_{n, \max }}\right)\right] .
$$

Якщо доступні дані стосуються максимальної дальності польоту із запасом 30 хвилин ( $t_{P}=0,5$ год), тоді максимальний запас палива без резерву розраховують з урахуванням припущення, що літак буде літати з крейсерською швидкістю

$$
L_{\text {nог. } \max }=L_{\text {пола } \max P}+V_{k p} t_{P} .
$$

Розрахунок енергоємності БТЛ на певный відстані польоту

Для визначення енергоефективності на заданій відстані обчислюють:

- масу необхідного палива:

$$
m_{n}=m_{3 n}\left(1-e^{-\frac{L_{n 0 q}}{B F}}\right) ;
$$

- масу резервного палива:

$$
m_{n . P}=\left(m_{3, n}-m_{n}\right)\left(1-e^{-\frac{V_{n p} t_{P}}{B F}}\right) ;
$$


- д доступне корисне навантаження:

$$
m_{\text {кор }}=m_{3, л}-m_{n}-m_{n . P} .
$$

Енергоефективність розраховують за допомогою рівняння (1).

\section{Результати дослідження}

Оцінювання паливної ефективності проводили у два етапи. По-перше, оцінювали енергоємність літаків на відстані польоту 1000 км та аналізували вплив пропорції крила та типу конструкції планера. По-друге, енергетичну ефективність літаків кожної групи розраховували на відстані від 500 до 2500 км.

Ефективність використання пального БТЛ на відстані польоту 1000 км, результати розрахунків енергоємності при дальності польоту 1000 км як функції подовження крила літаків показано на рис. 1.

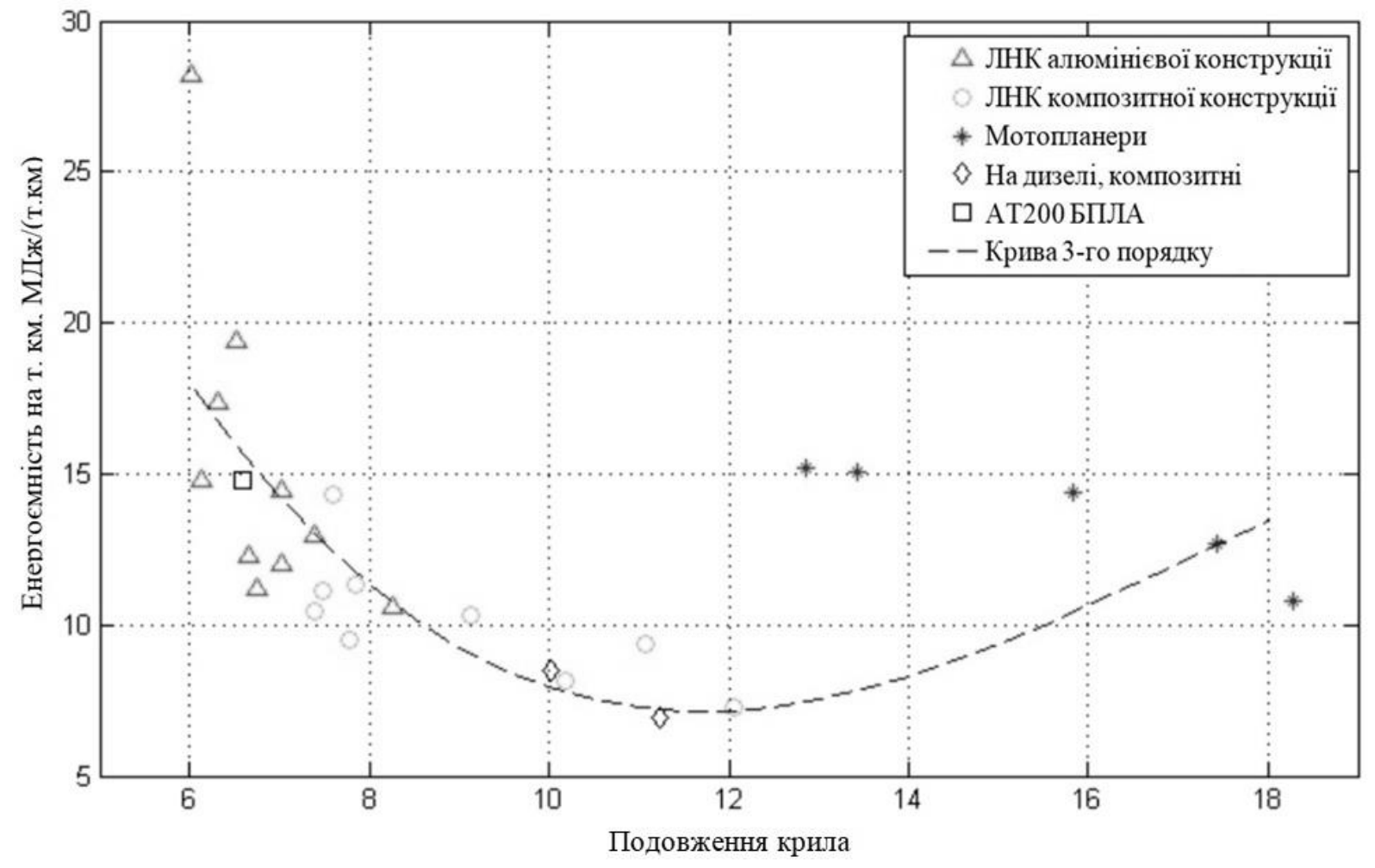

Рис 1. Енергоємність БТЛ на основі ЛНК та легких літаків на відстані польоту 1000 км

На рис. 1 показано залежність між енергоємністю (паливною ефрективністю) та подовженням крила літаків. Лише моторні планери старшого покоління з алюмінієвим планером залишаються осторонь. Це співвідношення було апроксимовано за допомогою кривої третього порядку (див. рис. 1) (два старіші планери виключені 3 даних регресії). Результати показують, що найкраща економія палива може бути очікувана у літаках з композитною конструкцією та подовженням крила приблизно від 11 до 12. Більш низька енергоефективність при менших пропорціях крила пояснюється збільшенням індукованого опору таких крил. При високих пропорціях крила ефективність експлуатації літаків також низька, оскільки їх крила оптимізовані для польоту на низькій швидкості, а не для подолання великих відстаней. Енергоємність турбогвинтового БТЛ АТ200 також показана на рис. 1. Незважаючи на більший 
розмір літака та різницю в силовій установці, він дуже добре відповідає загальній тенденції.

\section{Порівняння паливної економічності БТЛ економічністю інших вантажних літаків та наземного транспорту}

«Найбільш ефрективні» літаки кожної групи порівняно з вантажним літаком Boeing 737-800 (рис. 2). Дані для Boeing 737-800 використано з роботи [10]. Енергоємність наземного транспорту розраховується з припущенням, що він перевозить 400 кг вантажу з витратою 5 літрів дизельного палива на 100 км.

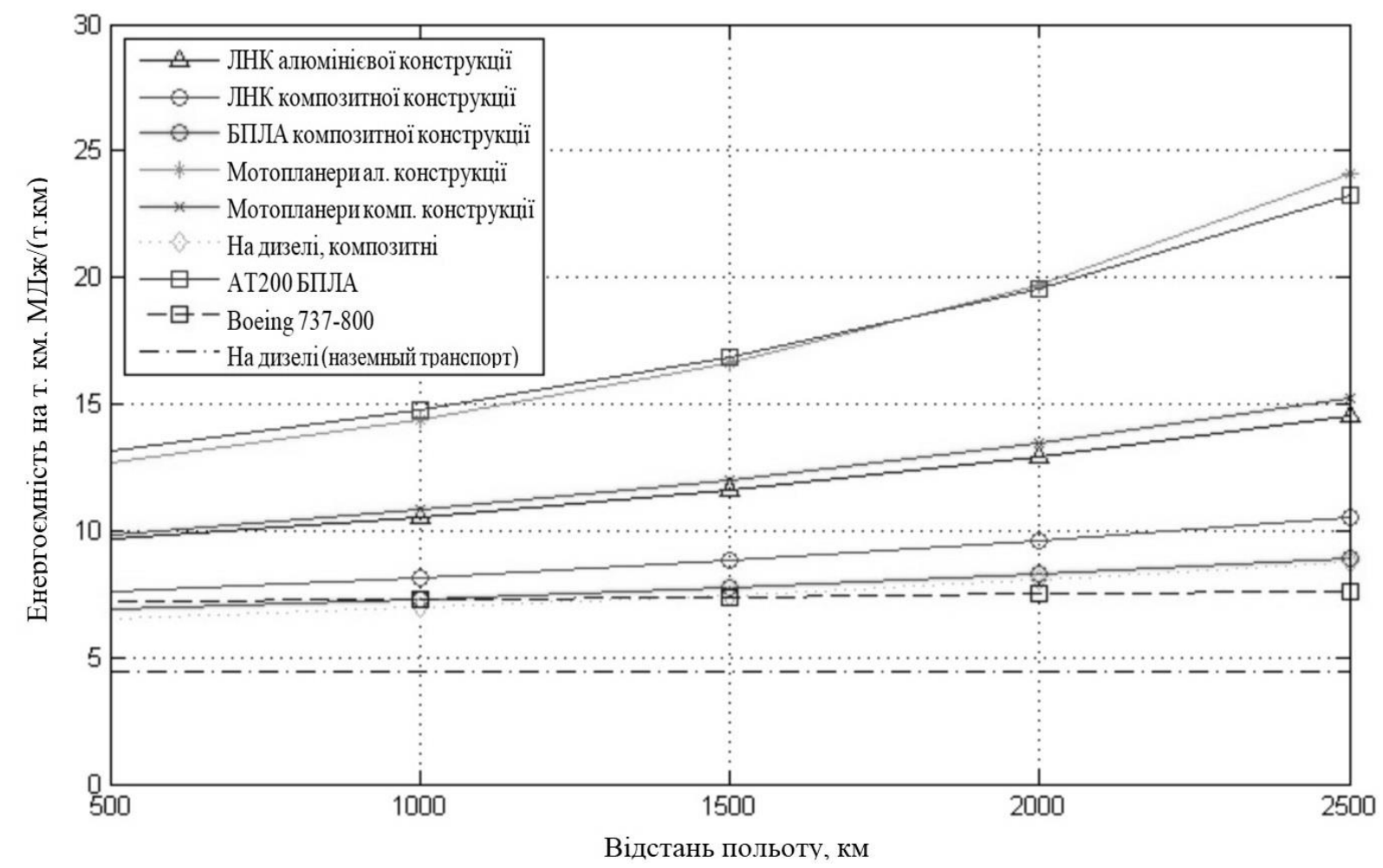

Рис. 2. Енергоємність БТЛ на основі енергоємності ЛНК та легких літальних апаратів на заданій відстані польоту

Результати показують, що енергоємність БТЛ на менших відстанях польоту (до 1000 км) буде такою же самою, що у нинішніх поколінь великих пілотованих вантажних літаків. На більших відстанях перевага реактивних вантажних літаків обумовлена їх більшою крейсерською швидкістю. У той же час ефективність БТЛ на основі ЛНК буде вдвічі більшою, ніж у більшого турбогвинтового БТЛ (АТ200), завдяки значно кращій питомій витраті палива у малих поршневих двигунах порівняно з турбогвинтовими двигунами.

\section{Висновки і перспективи}

Застосування безпілотних літальних систем знаходиться на початковій стадії, що характеризується відсутністю підстав для застосування безпілотних літальних апаратів у реальних технологічних процесах, хоча розвиток безпілотних літальних апаратів та їх елементів викликає підвищений інтерес. Вирішення цього протиріччя потребує вирішування різноманітних проблем 
концептуального, технічного, технологічного, методологічного, організаційноправового та нормативного характеру.

Загалом сьогодні застосування безпілотних літальних систем у цивільній галузі практично обмежується окремими випадками місцевих застосувань на користь вирішення поточних виробничих або економічних проблем, головним чином шляхом експериментальної процедури. Отже, зростання ринку безпілотних літальних систем, як очікується, забезпечить виникнення технічних та адміністративних бар'єрів, що обмежують використання безпілотних літальних систем у національному повітряному просторі.

Результати досліджень підтверджують, що для найкращої економії палива вантажний безпілотник на основі ЛНК зі звичайною компоновкою літака повинен мати композитну структуру та подовження крила, що дорівнює 10-12. при нинішньому поколінні великих пілотованих вантажних літаків, що досягають енергоефективності близько 7 ... 8 МДж/(т·км). Це набагато кращий показник, ніж 14 ... 24 МДж/(т·км) у випадку турбогвинтоваго варіанта БТЛ. Певною мірою та в окремих випадках такі БТЛ будуть конкурентоспроможними також автомобільному транспорту, енергоємність якого досягає приблизно 4 ... 5 МДж/(т·км).

Це дослідження слід розглядати як попередній крок до комплексного оцінювання та оптимізації транспортних систем БТЛ, включаючи сам літак, наземну інфраструктуру, експлуатацію тощо.

\section{Список літератури}

1. Харченко, В., Прусов Д. Анализ применения беспилотных авиационных систем гражданского назначения // В. Харченко, Д. Прусов - Национальный Авиационный Институт - Киев, 2012. - С. 118 - 130.

2. V.S. Serbezov Assessment of the fuel efficiency of unmanned cargo aircraft, based on general aviation aircraft - IOP Conf. Series: Materials Science and Engineering 664 - Bulgaria, 2019. - C. 59 - 66.

3. International Air Transport Association 2018 IATA cargo strategy (Retrieved June, 3, 2019)

4. Kallas S, Geoghegan-Quinn M, Darecki M, Edelstenne C, Enders T, Fernandez E and Hartman P Flightpath 2050 europe's vision for aviation Report of the high level group on aviation research, European commission, Report No. EUR 98 - Brussels, Belgium, 2011. - C. 44 - 52.

5. Amoiralis E.I. Tsili M A, Spathopoulos V and Hatziefremidis A Energy efficiency optimization in uavs: a review. In Materials Science Forum $792-2014$. C. $117-131$.

6. Valerdi R. Cost metrics for unmanned aerial vehicles Infotech@ Aerospace $7102-2005$. - C. $34-37$.

7. Stolaroff J K, Samaras C, O'Neill E R, Lubers A, Mitchell A S and Ceperley $D$ Energy use and life cycle greenhouse gas emissions of drones for commercial package delivery Nature communications 9(1) 409 - 2018. - C. 41 -49.

8. Gulden T.R. The Energy Implications of Drones for Package Delivery: A Geographic Information System Comparison - 2017. - C. 66-72.

9. Collins M.P. The future market for Large Unmanned Cargo Aircraft in the national airspace system Faculty of Lewis University Aviation \& Transportation Illinois USA - 2017. - C. $21-29$. 
10. Van Groningen R Cost Benefit Analysis Unmanned Cargo Aircraft: Case Study Stuttgart- Urumqi/Shenzen Erasmus University Rotterdam - Rotterdam, 2017. - C. $47-56$.

11. Lee J.J, Lukachko S.P, Waitz I.A. and Schafer A Historical and future trends in aircraft performance, cost, and emissions Annual Rev. Energy and the Environment 26(1) - 2001. - C. $167-200$.

12. Peeters P.M, Middel $\mathrm{J}$ and Hoolhorst A Fuel efficiency of commercial aircraft: an overview of historical and future trends NLR-CR-2005-669 - 2005. C. $89-102$.

13. Hasan $Y$ J, Sachs $F$ and Dauer J C Preliminary design study for a future unmanned cargo aircraft configuration. CEAS Aeronautical Journal 9(4) 571-86 2018. - C. $61-74$.

14. Burzlaff $M$ Aircraft Fuel Consumption-Estimation and Visualization, Department of Automotive and Aeronautical Engineering, Hamburg University of Applied Sciences) - Hamburg, 2001. - C. 47 -63.

\section{References}

1. Kharchenko V., Prusov D., Analysis of unmanned aircraft systems application in the civil field National Aviation University - Kiev, 2012 - P. $118-130$.

2. V.S. Serbezov Assessment of the fuel efficiency of unmanned cargo aircraft, based on general aviation aircraft - IOP Conf. Series: Materials Science and Engineering 664 - Bulgaria, 2019. - P. 59-66.

3. International Air Transport Association 2018 IATA cargo strategy (Retrieved June, 3, 2019)

4. Kallas S, Geoghegan-Quinn M, Darecki M, Edelstenne C, Enders T, Fernandez E and Hartman P Flightpath 2050 europe's vision for aviation Report of the high level group on aviation research, European commission, Report No. EUR 98 - Brussels, Belgium, 2011. - P. $44-52$.

5. Amoiralis E.I. Tsili M A, Spathopoulos $V$ and Hatziefremidis A Energy efficiency optimization in uavs: a review. In Materials Science Forum 792 - 2014. P. $117-131$.

6. Valerdi R. Cost metrics for unmanned aerial vehicles Infotech@ Aerospace 7102 - 2005. - P. $34-37$.

7. Stolaroff J K, Samaras C, O'Neill E R, Lubers A, Mitchell A S and Ceperley $D$ Energy use and life cycle greenhouse gas emissions of drones for commercial package delivery Nature communications 9(1) 409 - 2018. - P. 41 -49.

8. Gulden T.R. The Energy Implications of Drones for Package Delivery: A Geographic Information System Comparison - 2017. - P. 66 -72.

9. Collins M.P. The future market for Large Unmanned Cargo Aircraft in the national airspace system Faculty of Lewis University Aviation \& Transportation Illinois USA - 2017. - P. $21-29$.

10. Van Groningen R Cost Benefit Analysis Unmanned Cargo Aircraft: Case Study Stuttgart- Urumqi/Shenzen Erasmus University Rotterdam - Rotterdam, 2017. - P. $47-56$.

11. Lee J.J, Lukachko S.P, Waitz I.A. and Schafer A Historical and future trends in aircraft performance, cost, and emissions Annual Rev. Energy and the Environment 26(1) - 2001. - P. $167-200$. 
12. Peeters P.M, Middel $\mathrm{J}$ and Hoolhorst $A$ Fuel efficiency of commercial aircraft: an overview of historical and future trends NLR-CR-2005-669 - 2005. P. $89-102$.

13. Hasan $Y$ J, Sachs F and Dauer J C Preliminary design study for a future unmanned cargo aircraft configuration. CEAS Aeronautical Journal 9(4) 571-86 2018. - P. $61-74$.

14. Burzlaff M Aircraft Fuel Consumption-Estimation and Visualization, Department of Automotive and Aeronautical Engineering, Hamburg University of Applied Sciences) - Hamburg, 2001. - P. 47 -63.

Поступила в редакцию 21.10.2021, рассмотрена на редколлегии 22.10.2021

\section{Анализ топливной экономичности беспилотных транспортных самолетов}

Применение беспилотных летательных систем находится на начальной стадии, характеризуется отсутствием оснований для применения беспилотных летательных аппаратов в реальных технологических процессах, хотя развитие беспилотных летательных аппаратов и их элементов вызывает повышенный интерес. Разрешение этого противоречия потребует решения различных проблем концептуального, технического, технологического, методологического, организационно-правового и нормативного характера.

В целом на сегодняшний день применение беспилотных авиационных систем в гражданской сфере практически ограничено частными случаями локального использования в пользу решения текущих производственных или экономических проблем, в основном экспериментальным путем. Поэтому ожидается, что развитие рынка беспилотных авиационных систем обеспечит возможность устранения ряда технических и административных барьеров, которые ограничивают использование беспилотных авиационных систем в национальном воздушном пространстве. Следует также отметить все большее распространение беспилотных систем в транспортной сфере.

Проведение данного исследования было мотивировано растущим во всем мире интересом к беспилотным грузовым самолетам. Особое внимание при этом уделялось грузовым беспилотным летательным аппаратам на базе существующих обычных самолетов авиации общего назначения. Это следует рассматривать как предварительный шаг к комплексной оценке беспилотных транспортных систем грузовых самолетов. Цель состояла в том, чтобы оценить топливную эффективность таких беспилотных летательных аппаратов и наметить оптимальные значения некоторых из их ключевых конструктивных характеристик. Были исследованы 26 образцов очень легких и легких самолетов и мотопланеров. Данные взяты из открытых источников. Результаты показывают, что для максимальной экономии топлива грузовой беспилотный самолет должен иметь композитную конструкцию, поршневой двигатель и удлинение крыла от 10 до 12. Оценка топливной эфффективности на расстояниях от 500 до 2500 км свидетельствует о том, что такие грузовые беспилотники будут конкурентоспособны с большими пилотируемыми самолетами, коммерческими грузовыми самолетами, а также автомобильным транспортом. 
Ключевые слова: беспилотные летательные аппараты (БПЛА), беспилотный транспортный самолет (БТА), платформа для беспилотных транспортных самолетов (ПБТС), самолеты сверхлегкого класса (ССК).

\section{Analysis of the Fuel Efficiency of Unmanned Transport Aircraft}

The unmanned aircraft systems application is in the initial stage, which is characterized by a significant level of unmanned aircraft development and its elements, and by the lack of the basis of unmanned aircraft application in real technological processes. Resolution of this contradiction requires the solution of diverse problems of conceptual, technical, technological, methodological, organizational and legal - normative character.

In general, today the unmanned aircraft systems application in the civil field is practically limited by particular cases of local applications in favor of the solution of current production or economic problems, mainly by the experimental procedure. Therefore, the market growth of the unmanned aircraft systems is expected providing the capability of a number of technical and administrative barriers that restrict the use of unmanned aircraft systems in the national airspace. It should also be noted the increasing prevalence of unmanned systems in general transport.

This study was motivated by the globally increasing interest in unmanned cargo drones. It was focused particularly on cargo drones based on existing conventional general aviation airplanes and it should be regarded as a preliminary step towards the complex assessment of unmanned cargo aircraft transport systems. The aim was to estimate the fuel efficiency of such drones and to outline the optimums of some of their key design characteristics. A sample of 26 very light and light aircraft, and motorgliders was examined. The data was taken from open sources. The results outline that for best fuel economy the cargo drone should be a composite structure, piston engine airplane with wing aspect ratio of 10 to 12 . Fuel efficiency estimation at distances of 500 to $2500 \mathrm{~km}$ shows that such cargo drones would be competitive with large piloted commercial cargo airplanes as well as with the road transport.

Key words: Unmanned Aerial Vehicles (UAV), Unmanned Transport Aircraft (UTA), Platform for Unmanned Transport Aircraft (PUTA), Very Light Class Aircraft (VLA).

\section{Відомості про авторів:}

Долгих Вячеслав Сергійович -аспірант кафедри 103 «Проектування літаків і вертольотів», Національний аерокосмічний університет ім. М. $€$. Жуковського «Харківський авіаційний інститут», Україна, інженер-конструктор, ДП «Антонов», Україна e-mail: dolhykh@gmail.com, ORCID 0000-0002-0305-2370

\section{About the Authors:}

Viacheslav S. Dolhykh - post-graduate student of the Department of Airplanes and Helicopters Design, National Aerospace University named after M. Ye. Zhukovsky "Kharkiv Aviation Institute", ANTONOV SE design engineer, Kiev, Ukraine, e-mail: dolhykh@gmail.com, ORCID 0000-0002-0305-2370. 